\title{
ANALISIS PENGARUH PERDAGANGAN INTRA-REGIONAL DAN EKTRA-REGIONAL ASEAN TERHADAP PERTUMBUHAN EKONOMI NEGARA-NEGARA ASEAN-5
}

\author{
Baida Soraya \\ Program Pascasarjana, Universitas Negeri Medan \\ Jl. Williem Iskandar Ps. V Medan 20221, Telp. +6261-6613365 \\ Email: baidasoraya@yahoo.com
}

\begin{abstract}
Economy growth is one of indicators of people prosperity in a country. ASEAN is a type of economic integration which aim to increase economic growth of member countries. Intra-regional and extra-regional trade is kind of trade agreement which aim to increase the trade rate and economic growth. However, the rate of extra-regional trade in every ASEAN-5 countries is higher than intra-regional trade. The objective of this research is to analyze the factors which effect the economic growth of ASEAN-5 countries during 2007-2011. With random effect model in pooled data processing, the research result described that extra-regional trade of ASEAN, foreign direct investment, inflation, and the population described positive and significant effect to economic growth of every ASEAN-5 countries. Whereas, intra-regional trade of ASEAN effect positive and insignificant to the economic growth of ASEAN-5 countries.
\end{abstract}

Key words: ASEAN-5 economic growth, intra-regional trade of ASEAN, extra-regional trade of ASEAN.

\section{PENDAHULUAN}

$\mathcal{P}$ ertumbuhan ekonomi merupakan suatu proses perubahan kondisi perekonomian suatu negara menuju ke arah yang lebih baik. Menurut Kutznets dalam Todaro danSmith (2003:91) pertumbuhan ekonomi adalah kenaikan kapasitas dalam jangka panjang dari negara yang bersangkutan untuk menyediakan berbagai barang ekonomi kepada penduduknya.

Perdagangan internasional merupakan salah satu kegiatan di dalam perekonomian yang terdiri dari kegiatan ekspor (mengirim barang atau jasa ke suatu wilayah ke wilayah lain) dan impor (mendatangkan barang atau jasa ke suatu wilayah ke wilayah lain). Namun di lain sisi, Krugman dan Obstfeld (2004:275) menyatakan bahwa perdagangan internasional berpeluang menimbukan efek eksploitasi terhadap negara berkembang dan rusaknya industri lokal. 
Untuk mengatasi fenomena tersebut, banyak negara telah membentuk sebuah integrasi ekonomi. Integrasi ekonomi bertujuan untuk meningkatkan kesejahteraan negara anggota dan menciptakan stabilitas yang tinggi (Salvatore, 1997:05). ASEAN Free Trade Area (AFTA) merupakan salah satu bentuk perjanjian kerjasama di bidang ekonomi yang disepakati oleh seluruh negara anggota ASEAN tahun 1992 (Deperindag, 2002:01).

Secara umum bahwa perdagangan dipengaruhi oleh banyak faktor dinataranya adalah tingkat inflasi, jumlah investasi, dan jumlah populasi disuatu negara. (Mankiw, 2007:16). Berdasarkan fakta ini dapat diketahui bahwa inflasi, jumlah investasi dan populasi dapat berdampak postif terhadap pertumbuhan eknomi suatu bangsa. Tingkat inflasi yang masih rendah yaitu berkisar 0-9 \% akan meningkatkan pertumbuhan ekonomi suatu bangsa. Jumlah populasi yang tinggi juga akan meningkatkan pertumbuhan ekonomi suatu bangsa apabila tingginya jumlah populasi tersebut dapat diberdayakan secara maksimal. Jumlah populasi yang rendah akan menuntut suatu bangsa untuk menyerap tenaga kerja dari negara lain untuk meningkatkan pertumbuhan ekonomi negaranya (Muchtolifah, 2010:23-29). Demikian halnya dengan jumlah investasi yang semakin tinggi, yang juga akan meningkatkan pertumbuhan ekonomi melalui masuknya investor-investor asing yang menanamkan modal baik dalam bentuk obligasi, saham dan lainnya.

Dalam melakukan perdagangan, negara anggota ASEAN tidak hanya berinteraksi dengan sesama negara anggota. Oleh karena itu, pada umumnya perdagangan yang dilakukan oleh negara-negara ASEAN terdiri dari perdagangan intra-regional dan perdagangan ekstra-regional. Perdagangan intra-regional meliputi perdagangan satu negara ASEAN sesama negara anggota ASEAN. Sedangkan perdagangan ekstra-regional meliputi perdagangan satu negara ASEAN terhadap negara di luar anggota ASEAN. Perkembangan Ner Intra dan Ekstra Ekspor negara ASEAN-5 dapat dilihat pada tabel berikut:

Tabel 1. Perkembangan Perdagangan Net Intra Ekspor Indonesia, Malaysia, \& Singapura Tahun 2007-2009 (juta US\$)

\begin{tabular}{ccccccc}
\hline \multirow{2}{*}{ Tahun } & \multicolumn{2}{c}{ Indonesia } & \multicolumn{2}{c}{ Malaysia } & \multicolumn{2}{c}{ Singapura } \\
\cline { 2 - 7 } & Net Intra & $\begin{array}{c}\text { Pertumbuhan } \\
\text { Ekspor }\end{array}$ & $\begin{array}{c}\text { Net Intra } \\
\text { (\%) }\end{array}$ & $\begin{array}{c}\text { Pertumbuha } \\
\text { Ekspor }\end{array}$ & $\begin{array}{c}\text { Net Intra } \\
\text { Ekspor }\end{array}$ & $\begin{array}{c}\text { Pertumbuhan } \\
(\%)\end{array}$ \\
\hline 2007 & $-1500,00$ & - & 7979,70 & - & 29153,30 & - \\
2008 & $-13820,90$ & $-821,39$ & 15726,10 & 97,08 & 31599,20 & 8,39 \\
2009 & $-3118,5$ & 77,44 & 8664,9 & $-44,90$ & 22598,9 & $-28,48$ \\
\hline
\end{tabular}

Sumber : ASEAN Statistical Year Book 2010, ASEAN Secretariat (diolah)

Tabel 2. Perkembangan Perdagangan Net Intra Ekspor Thailand \& Filipina Tahun 20072009 (juta US\$)

\begin{tabular}{ccccc}
\hline \multirow{2}{*}{ Tahun } & \multicolumn{2}{c}{ Thailand } & \multicolumn{2}{c}{ Filipina } \\
\cline { 2 - 5 } & Net Intra Ekspor & Pertumbuhan (\%) & Net Intra Ekspor & Pertumbuhan (\%) \\
\hline 2007 & 7901,70 & - & $-4843,20$ & - \\
2008 & 9598,80 & 21,48 & $-7235,00$ & $-49,38$ \\
2009 & 5731,1 & $-40,29$ & $-5722,7$ & 20,90 \\
\hline
\end{tabular}


Tabel 3. Perkembangan Net Ekstra Ekspor Indonesia, Malaysia, \& Singapura Tahun 2007-2009 (juta US\$)

\begin{tabular}{ccccccc}
\hline \multirow{3}{*}{ Tahun } & \multicolumn{2}{c}{ Indonesia } & \multicolumn{2}{c}{ Malaysia } & \multicolumn{2}{c}{ Singapura } \\
\cline { 2 - 7 } & $\begin{array}{c}\text { Net Ekstra } \\
\text { Ekspor }\end{array}$ & $\begin{array}{c}\text { Pertumbuhan } \\
(\%)\end{array}$ & $\begin{array}{c}\text { Net Ekstra } \\
\text { Ekspor }\end{array}$ & $\begin{array}{c}\text { Pertumbuhan } \\
(\%)\end{array}$ & $\begin{array}{c}\text { Net Ekstra } \\
\text { Ekspor }\end{array}$ & $\begin{array}{c}\text { Pertumbuhan } \\
(\%)\end{array}$ \\
\hline 2007 & 41127,50 & - & 21315,60 & - & 6989,20 & - \\
2008 & 21644,00 & $-47,37$ & 34471,00 & 61,72 & $-105093,6$ & 1603,66 \\
2009 & 22799,3 & 5,34 & 24895,6 & $-27,787$ & 1448,9 & $-101,38$ \\
\hline
\end{tabular}

Sumber : ASEAN Statistical Year Book 2010, ASEAN Secretariat (diolah)

Tabel 4. Perkembangan Net Ekstra Ekspor Thailand\&Filipina Tahun 2007-2009 (juta US\$)

\begin{tabular}{ccccc}
\hline \multirow{2}{*}{ Tahun } & \multicolumn{2}{c}{ Thailand } & \multicolumn{2}{c}{ Filipina } \\
\cline { 2 - 5 } & Net Ekstra Ekspor & Pertumbuhan (\%) & Net Ekstra Ekspor & Pertumbuhan (\%) \\
\hline 2007 & 5703,80 & - & $-204,80$ & - \\
2008 & $-12199,70$ & 42,19 & $-385,20$ & $-88,09$ \\
2009 & 12996,5 & 60,07 & $-1476,7$ & $-283,36$ \\
\hline
\end{tabular}

Sumber : ASEAN Statistical Year Book 2010, ASEAN Secretariat (diolah)

Dengan perolehan nilai perdagangan ekstra-regional yang lebih besar dibandingkan nilai perdagangan intra-regional dapat disimpulkan bahwa setiap negara-negara ASEAN belum mampu untuk memanfaatkan integrasi ekonomi yang dibentuk secara maksimal karena setiap negara ASEAN belum dapat untuk secara konsisten meningkatkan persentase pertumbuhan net-ekstra Ekspor. Ketidakmampuan setiap negara-negara ASEAN untuk meningkatkan persentase pertumbuhan net-ekstra kearah positif disebabkan oleh banyak faktor penghambat seperti terjadinya krisis global pada tahun 2009.

Melihat berbagai fenomena yang telah diuraikan sebelumnya, maka perlu diadakan penelitian mengenai besarnya dampak kegiatan integrasi ekonomi khususnya integrasi ekonomi ASEAN terhadap peningkatan kesejahteraan negara-negara anggota ASEAN dan bagaimana pengaruh perdagangan intra-regional ASEAN, perdagangan ekstraregional ASEAN, investasi asing langsung, tingkat inflasi, dan jumlah populasi terhadap pertumbuhan ekonomi setiap negara anggota ASEAN-5. tujuan penelitian ini adalah untuk menganalisis pengaruh perdagangan intra-regional ASEAN, perdagangan ekstraregional ASEAN, investasi asing langsung, tingkat inflasi, dan jumlah populasi terhadap pertumbuhan ekonomi setiapnegara anggota ASEAN-5.

Penelitian ini akan menganalisis bagaimana pengaruh perdagangan intra-regional ASEAN dan perdagangan ekstra-regional ASEAN serta faktor-faktor lain terhadap perekonomian negara-negara ASEAN-5 yang diukur dengan produk domestic bruto (PDB) masing-masing negara tersebut. 


\section{METODE PENELITIAN}

Penelitian ini menganalisis faktor-faktor yang mempengaruhi pertumbuhan ekonomi negara-negara anggota ASEAN-5 (Indonesia, Malaysia, Singapura, Thailand, dan Filipina). Faktor-faktor yang diduga mempengaruhi pertumbuhan ekonomi setiap negara anggota ASEAN-5 adalah nilai total perdagangan intra-regional, nilai perdagangan ekstra-regional, nilai investasi asing langsung, tingkat inflasi, dan jumlah populasi.

Data yang dipergunakan dalam penelitian ini adalah data sekunder tahunan, yang merupakan data time series dan cross section (data panel) dengan rentang waktu dari tahun 2007 sampai dengan tahun 2011 dan diolah menggunakan software Eviews 5. Adapun sumber data yang diperoleh adalah sebagai berikut:

Tabel 5. Variabel dan Sumber Data Penelitian

\begin{tabular}{ll}
\hline \multicolumn{1}{c}{ Variabel } & Sumber data \\
\hline $\begin{array}{ll}\text { Pertumbuhan ekonomi (PDB/GDP) } \\
\text { Perdagangan Intra-regional ASEAN }\end{array}$ & Penn World Table 7.1, University of Pennsylvania \\
Perdagangan Ekstra-regional ASEAN & ASEAN Statistical Yearbook, ASEAN Secretariat \\
Investasi Asing Langsung & Penn World Table 7.1, University of Pennsylvania \\
Tingkat Inflasi & Penn World Table 7.1, University of Pennsylvania \\
Populasi & Penn World Table 7.1, University of Pennsylvania
\end{tabular}

Sumber: Penulis

Penelitian ini akan menguji faktor-faktor yang berpengaruh terhadap pertumbuhan ekonomi negara-negara anggota ASEAN khususnya negara-negara ASEAN-5. Dengan demikian, metode penelitian ini akan menggunakan metode pengujian data panel.

Pemilihan variabel dalam penelitian ini berdasarkan penelitian sebelumnya yang dilakukan oleh Wooster et al. (2006:42-49). Penulis beranggapan bahwa variabel yang dapat dimasukkan dalam penelitian ini adalah variabel yang secara langsung berpengaruh terhadap perdagangan internasional yang pada akhirnya akan memberikan pengaruh terhadap pertumbuhan ekonomi. Dengan demikian variabel endogen pada penelitian ini adalah pertumbuhan ekonomi negara-negara ASEAN-5. Sedangkan variabel eksogennya adalah nilai total perdagangan intra-regional, nilai total perdagangan ekstra-regional, investasi asing langsung, tingkat inflasi, dan jumlah populasi.

Dengan demikian, model analisis yang akan digunakan pada penelitian ini adalah:

$\log P D B_{i t}=B_{0}+B_{1} \log / T_{i t}+B_{2}{\log E T_{i t}}_{1} B_{3} \log F D I_{i t}+B_{4} \log _{I n f} f_{i t}+B_{5}{\log P o p_{i t}}+\mu$

di mana:

$P D B_{\text {it }} \quad=$ pertumbuhan ekonomi negara $i$ yang diproxy dengan PDB pada tahun $t$ (million US\$) 


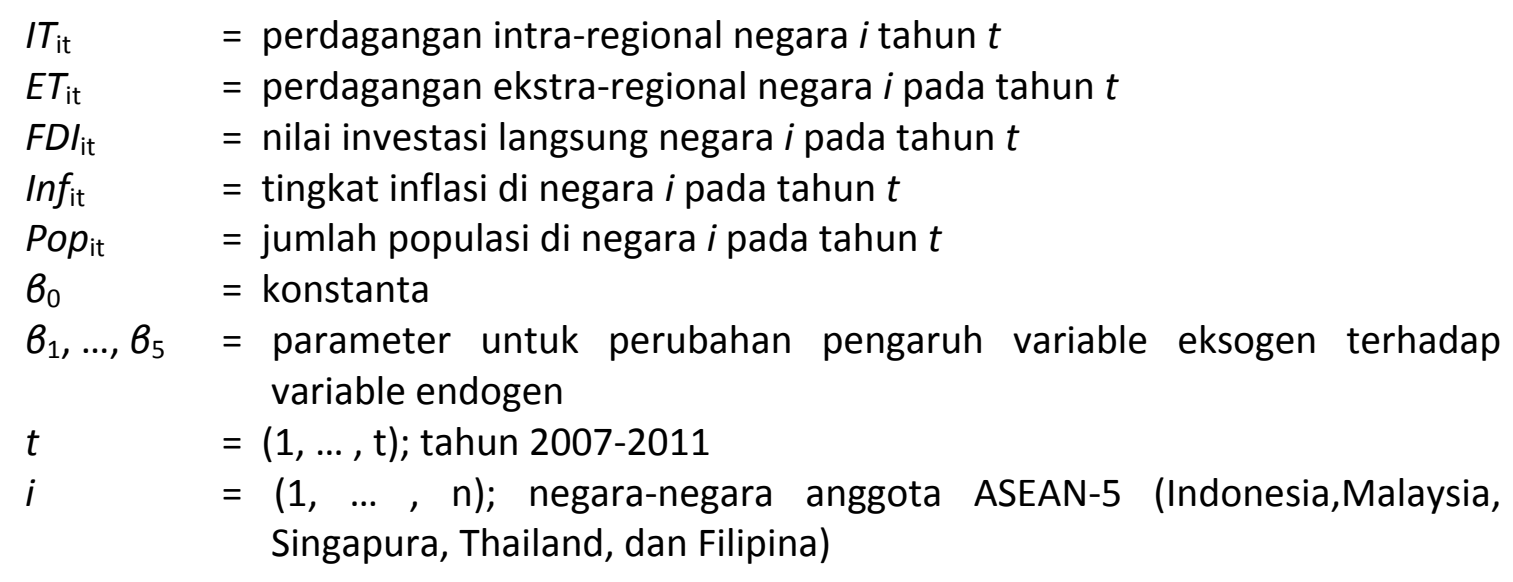

\section{Analisis Regresi Data Panel (Regression of Pooled Data)}

Metode yang digunakan untuk menganalisis pengaruh perdagangan intra-regional ASEAN dan ekstra-regional ASEAN terhadap pertumbuhan ekonomi negara-negara ASEAN-5 dilakukan dengan model regresi least squares pooled data dengan teknik.

\section{Model Efek Tetap (Fixed Effect Model)}

Penaksiran model regresi data panel Fixed Effect bergantung pada asumsi titik potong, koefesien slope, dan error term. Pendekatan metode kuadrat terkecil biasa adalah asumsi intercept dan slope dari persamaan regresi (model) yang dianggap konstan baik antarkomoditas maupun antarwaktu (all coefficients constant across time and individuals). Adanya variabel-variabel yang tidak semuanya masuk dalam persamaan model memungkinkan adanya intercept yang tidak konstan. Atau dengan kata lain, intercept ini mungkin akan berubah untuk setiap individu dan waktu. Pendekatan ini dalam literatur dikenal dengan sebutan model efek tetap (fixed effect model/FEM).

\section{Model Efek Random (Random Effect Model, REM)}

Penaksiran model regresi data panel Random Effect akan menghasilkan model regresi dengan error term yang terdiri dari dua komponen, yaitu komponen cross section dan komponen error. Komponen error merupakan kombinasi time series error dan cross section error. Komponen error ini tidak diamati atau unobservable or latent variable. Oleh sebab itu asumsi di atas harus mengikuti: $E\left(E_{i t}\right)=0$ dan $\operatorname{var}\left(E_{i t}\right)=\sigma^{2} \varepsilon+\sigma^{2} e$ dan $\sigma^{2} e$ $=0$. Asumsi homoskedastisitas dari $\mathrm{E}_{\mathrm{it}}$ menunjukkan korelasi antara $\mathrm{E}\left(\varepsilon_{\mathrm{it}} \varepsilon_{\mathrm{js}}\right)$, yaitu:

$$
\operatorname{corr}\left(E_{i t}, E_{i s}\right)=\frac{o^{2} \mathrm{e}}{o^{2} e+o^{2} \varepsilon}
$$

Ada dua sifat dari koefisien korelasi ini: 1) pada unit time series tertentu, nilai korelasi antara error pada dua waktu yang berbeda tetap sama, tidak masalah berapa besar jarak antar dua periode waktu tersebut, 2) struktur korelasi tetap sama untuk semua unit cross section dan identik untuk semua anggota panel. 


\section{Pemilihan Model}

Untuk mengetahui model Pooled Least Square (PLS) atau Fixed Effect Model (FEM) yang akan dipilih untuk estimasi data dapat dilakukan dengan uji F-test atau uji Chow Test.

\section{Uji Chow (Chow Test)}

Seperti yang telah ketahui, terkadang asumsi bahwa setiap unit cross section memiliki perilaku yang sama cenderung tidak realistis mengingat dimungkinkan saja setiap unit cross section memiliki perilaku yang berbeda.Untuk itu dipergunakan Chow Test. Dasar penolakan terhadap hipotesa nol tersebut adalah dengan menggunakan $\mathrm{F}$ Statistik seperti yang dirumuskan oleh Chow sebagai berikut:

$$
\text { CHOW }=\frac{(\text { RSSS-URSS }) /(N-1)}{U R S S /(N T-N-K)}
$$

Di mana:

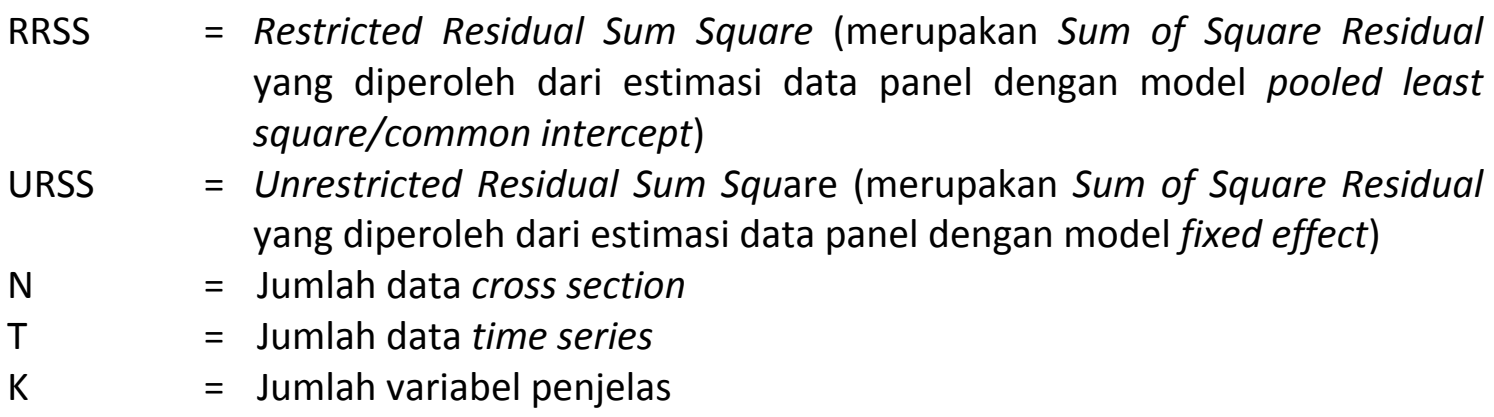

Pengujian ini mengikuti distribusi $F$ statistik yaitu FN-1, NT-N-K. Jika nilai CHOW Statistics (F Stat) hasil pengujian lebih besar dari $\mathrm{F}$ Tabel, maka cukup bukti untuk melakukan penolakan terhadap hipotesa nol sehingga model yang akan digunakan adalah model fixed effect, begitu juga sebaliknya.

\section{Uji Haussman (Haussman Test)}

Pengujian ini dilakukan untuk menentukan apakah model fixed effect atau random effect yang dipilih. Pengujian ini dilakukan dengan hipotesa sebagai berikut:

$\begin{array}{lll}\mathrm{H}_{\mathrm{o}} & : & \text { Model Random Effect } \\ \mathrm{H}_{1} & : & \text { Model Fixed Effect }\end{array}$

Dasar penolakan $\mathrm{H}_{0}$ adalah dengan menggunakan pertimbangan statistik Chi Square. Jika Chi Square statistik > Chi Square table maka $\mathrm{H}_{0}$ ditolak (model yang digunakan adalah Fixed Effect), dan sebaliknya.

Apabila pada model efek tetap, perbedaan individu dan atau antarwaktu dicerminkan melalui intercept, maka pada model efek random, perbedaan tersebut diakomodasi lewat error. 


\section{Pengujian Hipotesis Individual (Uji t)}

Uji t adalah uji yang biasa digunakan oleh para ahli ekonometrika untuk menguji hipotesis tentang koefisien slope regresi secara individual. Uji t mudah digunakan karena menjelaskan perbedaan-perbedaan unit-unit pengukuran variabel dan deviasi standar dari koefisien yang diestimasi. Nilai kritis t dapat dilihat dari Tabel t. Aturan keputusan uji $t$ adalah sebagai berikut "Menolak $H_{0}$ jika $\left|t_{h}\right|>t_{t}$ dan jika tanda yang dimiliki oleh koefisien seperti dinyatakan dalam hipotesis alternatif. Tidak menolak jika sebaliknya.

\section{Pengujian Hipotesis Serempak (Uji F)}

Uji F adalah suatu cara menguji hipotesis nol yang melibatkan lebih dari satu koefisien. Keputusan menggunakan uji $\mathrm{F}$ adalah menolak hipotesi nol apabila nilai $\mathrm{F}$ hasil hitung estimasi persamaan lebih besar daripada nilai kritis $F$ atau "menolak Ho jika $F>F_{t}$ dan Tidak Menolak $\mathrm{H}_{0}$ jika $\mathrm{F}<\mathrm{F}_{\mathrm{t}}$.

\section{Koefisien Determinasi $\left(\mathbf{R}^{2}\right)$}

Koefisien determinasi adalah ukuran variasi total pada peubah tak bebas yang dapat dijelaskan oleh hubungannya dengan peubah bebas. Koefisien determinasi juga disebut sebagai $R^{2}$. Untukmenghitung koefisien determinasi digunakan rumus sebagai berikut:

$$
\mathrm{R}^{2}=\frac{S S R}{T S S}
$$

SSE (Sum of Square Error) menunjukkan jumlah total kuadrat peubah tak bebas yang tidak dijelaskan oleh garis regresi kuadrat terkecil. Sedangkan SSR (Sum of Square Regression) merupakan jumlah total kuadrat yang dapat dijelaskan oleh garis regresi sedangkan TSS (Total Sum of Square) merupakan jumlah SSE dan SSR.

\section{HASIL DAN PEMBAHASAN}

Tahapan awal pengujian data menggunakan estimasi dari Uji Chow (Chow Test). Menurut Sukmawati (2011:30), apabila hasil dari Chow Test signifikan (probability dari Chow < taraf nyata 10 persen) maka $\mathrm{H}_{0}$ ditolak, artinya Fixed Effect digun/akan. Probability dari Chow $(0.00)<$ taraf nyata $(10 \%)$, maka tolak $\mathrm{H}_{0}$ artinya Fixed Effect yang digunakan. Hipotesis dari uji ini yaitu:

\section{$\mathrm{H}_{0}$ : Model pooled least square $\mathrm{H}_{1}$ : Model Fixed Effect}

Hasil dari estimasi Uji Chow tersebut dapat dilihat dalam Tabel 4.7 di bawah ini.

Tabel 6. Hasil Estimasi Uji Chow (Chow Test)

\begin{tabular}{cccc}
\hline Effects Test & Statistic & d.f. & Prob. \\
\hline Cross-section F & 6,434227 & $(4,15)$ & 0.0032 \\
\hline
\end{tabular}

Sumber: Eviews 6.0 
Hasil perhitungan menunjukkan bahwa Uji Chow dari penelitian ini adalah signifikan pada taraf nyata 5\% (0.05). Hal ini ditunjukkan dengan probability dari Chow (0.0032) yang lebih kecil dari taraf nyata 5\% (0.05). Dengan demikian, kesimpulan sementara yang dapat diambil yaitu penelitian ini menggunakan metode Fixed Effect Model.

\section{Uji Haussman}

Tahap selanjutnya dari pemilihan metode data panel yaitu penetapan model yang digunakan, apakah Efek Tetap (Fixed Effect) atau Efek Random (Random Effect) didasarkan pada uji Hausman (Hausman's test of specification model). Hipotesis yang digunakan adalah:

$$
\begin{array}{ll}
\mathrm{H}_{0} & \text { : Estimator random konsisten } \\
\mathrm{H}_{1} & \text { : Estimator random tidak konsisten }
\end{array}
$$

Hasil dari Uji Haussman dapat dilihat pada Tabel 4.8. berikut ini:

Tabel 7. Hasil Estimasi Uji Haussman

\begin{tabular}{lccc}
\hline \multicolumn{1}{c}{ Test Summary } & Chi-Sq. Statistic & Chi-Sq. d.f. & Prob. \\
\hline Cross-section random & 0.000000 & 5 & 1.0000 \\
\hline Sumber: Eviews 6.0 & & &
\end{tabular}

Hasil uji Haussman menunjukkan hasil yang tidak signifikan. Hal ini dapat dilihat nilai probability yaitu sebesar 1.000 yang lebih besar daripada taraf nyata $10 \%$ atau 0.10 . Dengan demikian, dapat disimpulkan bahwa penelitian ini menggunakan model efek random (Random Effect Model).

\section{Estimasi Pertumbuhan Ekonomi Negara-Negara Aggota ASEAN-5}

Salah satu metode yang dapat dilakukan untuk mengestimasi model data panel adalah metode Generalized Least-Square (GLS). Menurut Gujarati dan Porter (2010:472), metode GLS adalah OLS (ordinary least-square) pada variabel-variabel yang telah ditransformasikan yang memenuhi asumsi-asumsi standar kuadrat terkecil. Jadi, estimator yang kemudian diperoleh (disebut juga estimator GLS) adalah estimator yang telah bersifat BLUE (Best Linear Unbiased Estimate).

Persamaan dari fungsi pertumbuhan ekonomi negara-negara anggota ASEAN-5 adalah sebagai berikut:

1. Persamaan dari fungsi pertumbuhan ekonomi Indonesia:

$$
\begin{aligned}
\operatorname{LOG}\left(G D P \_I D N\right)= & -3,425+0,403 * \text { LOG(ET_IDN) }+0,098 * \text { LOG(FDI_IDN })+ \\
& 2,552 * \text { LOG }(I H K \text { IDN })+0,246 * \text { LOG }\left(P O P \_I D N\right)
\end{aligned}
$$

2. Persamaan dari fungsi pertumbuhan ekonomi Malaysia:

$$
\begin{aligned}
& \text { LOG(GDP_MYS) }=-3,441+0,403 * \text { LOG(ET_MYS) }+0,098 * \text { LOG(FDI_MYS) + } \\
& \text { 2,552*LOG(IHK_MYS) +0,246*LOG(POP_MYS) }
\end{aligned}
$$

3. Persamaan dari fungsi pertumbuhan ekonomi Singapura: 
LOG(GDP_SGP) $=-3,454+0,403 *$ LOG(ET_SGP) $+0,098 *$ LOG(FDI_SGP) + 2,552*LOG(IHK_SGP) +0,246*LOG(POP_SGP)

4. Persamaan dari fungsi pertumbuhan ekonomi Thailand:

LOG(GDP_THA $)=-3,478+0,403 *$ LOG(ET_THA $)+0,098 *$ LOG(FDI_THA $)+$ $2,552 *$ LOG $($ IHK_THA) $+0,246 *$ LOG (POP_THA)

\section{Persamaan dari fungsi pertumbuhan ekonomi Filipina:}

LOG(GDP_PHL) $=-3,502+0,403 *$ LOG(ET_PHL) $+0,098 *$ LOG(FDI_PHL) + 2,552*LOG(IHK_PHL) + 0,246*LOG(POP_PHL)

Faktor-Faktor yang Mempengaruhi Ekonomi Negara-Negara ASEAN-5

\section{Perdagangan Ekstra-Regional ASEAN}

Hipotesis penelitian ini menyatakan bahwa perdagangan ekstra-regional ASEAN memiliki pengaruh yang positif, artinya peningkatan nilai perdagangan ekstra-regional ASEAN akan menyebabkan pertumbuhan ekonomi negara-negara ASEAN-5 (Indonesia, Malaysia, Singapura, Thailand, dan Filipina) meningkat. Berdasarkan hasil analisis regresi data panel pertumbuhan ekonomi negara-negara ASEAN-5 diperoleh nilai elastisitas sebesar 0,40 persen, yang artinya bila terjadi kenaikan pada nilai perdagangan ektra-regional ASEAN-5 sebesar satu persen akan mengakibatkan pertumbuhan ekonomi negara-negara ASEAN-5 naik sebesar 0,40 persen.

Nilai perdagangan ektra-regional ASEAN-5 dapat berpengaruh positif terhadap pertumbuhan ekonomi dapat disebabkan oleh terbukanya kesempatan baru bagi industri untuk berkembang menjadi lebih baik, selain itu juga dapat meningkatkan keuntungan bagi masing-masing negara yang sedang terlibat dalam kegiatan ekonomi. Hal ini sesuai dengan pernyataan Todaro dan Smith (2003:423) yang menyebutkan bahwa integrasi ekonomi antarnegara akan berdampak positif terhadap pengembangan industri, melalui perdagangan antarnegara maka akan membuka kesempatan baru bagi indstri yang sedang berkembang baik sector-sektor yang belum dibangun maupun sector-sektor industri yang sangat membutuhkan perluasan pasar.

\section{Perdagangan Intra-Regional ASEAN}

Variabel perdagangan intra-regional pada penelitian ini tidak berpengaruh terhadap pertumbuhan ekonomi negara-negara ASEAN hal ini disebabkan oleh tidak semua kegiatan integarsi ekonomi dapat memberikan pengaruh yang signifikan terhadap pertumbuhan ekonomi suatu negara apalagi apabila dilakukan perhitungan terhadap pendapatan per kapita. Hal ini telah dibuktikan oleh penelitian Viner (1950) tentang penciptaan perdagangan dan pengalihan perdagangan yang menyimpulkan bahwa pengaruh integrasi ekonomi dan pertumbuhan perdagangan per pendapatan per kapita tidak terlalu besar. la juga menemukan bahwa tidak semua perdagangan dengan hambatan-hambatan yang diberlakukan dapat memperbaiki kesejahteraan.

Nilai perdagangan intra-regional yang tidak berpengaruh secara signifikan terhadap pertumbuhan ekonomi negara ASEAN-5 dapat juga disebabkan oleh pemberlakuan 
tarif yang tinggi oleh negara ekonomi yang kuat terhadap negara dengan perekonomian yang lebih rendah, sehingga negara tersebut mengalami kesulitan dalam melakukan perdagangan hasil produksi maupun jasa dari negara tersebut yang pada akhirnya negara dengan perekonomian yang lebih rendah akan memperoleh keuntungan yang relatif lebih sedikit. Hal ini sesuai dengan penelitian yang dilakukan oleh Krugman (1993:279) yang menyatakan bahwa kegiatan integrasi ekonomi dapat memberikan dampak pada penurunan kesejahteraan hidup masyarakat jika terdapat negara ekonomi kuat yang memberlakukan tarif yang tinggi terhadap negara yang lain.

\section{Investasi Asing Langsung}

Salah satu tujuan dari kegiatan investasi asing langsung di suatu negara adalah untuk meningkatkan kegiatan produksi yang dapat meningkatkan jumlah ekspor negara tersebut. Peningkatan jumlah ekspor ini pada akhirnya juga akan meningkatkan pertumbuhan ekonomi. Hasil estimasi penelitian ini menunjukkan bahwa variabel investasi asing langsung memiki elastisitas sebesar 0,09 persen. Nilai elastisitas tersebut memiliki arti bahwa jika nilai investasi asing langsung meningkat sebesar 1 persen akan menyebabkan pertumbuhan ekonomi negara-negara ASEAN-5 meningkat sebesar 0,09 persen.

Investasi asing langsung berdampak positif terhadap pertumbuhan ekonomi suatu bangsa yang mana negara penerima investasi asing langsung tersebut akan menerima keuntungan berupa modal, akses terhadap teknologi dan pasar yang pada akhirnya akan berpengaruh terhadap pertumbuhan ekonomi. Hal ini sesuai dengan penelitian Wacziarg (2001:393-429) yang meyatakan bahwa perdagangan mempengaruhi pertumbuhan ekonomi dan turut menaikkan investasi domestik.

\section{Tingkat Inflasi}

Berdasarkan hasil estimasi penelitian ini, variable tingkat inflasi memiki elastisitas sebesar 2,55 persen. Nilai elastisitas tersebut memiliki arti bahwa jika tingkat inflasi meningkat sebesar 1 persen akan menyebabkan pertumbuhan ekonomi negara-negara ASEAN-5 meningkat sebesar 2,55 persen. Hal ini dikarenakan oleh meningkatnya konsumsi masyarakat sehingga dapat meningkatkan produksi disuatu negara atau wilayah. Dengan demikian tingkat inflasi negara-negara ASEAN-5 yang cenderung berada pada tingkat inflasi rendah (0-9\%) dapat berpengaruh positif bagi perekonomian negara-negara tersebut terutama dalam jangka waktu pendek. Hal ini sesuai dengan Nopirin (2012:33) yang menyatakan bahwa tingkat inflasi dapat meningkatkan konsumsi masyarakat sehingga dapat meningkatkan produksi di suatu negara atau wilayah.

Inflasi meningkat dapat meningkatkan pertumbuhan perekonomian di dalam suatu negara atau wilayah akibat terjadinya kelebihan permintaan yang menyebabkan peningkatan harga sampai pada level tertentu yang pada akhirnya akan meningkatkan pertumbuhan perekonomian. Hal ini sesuai dengan pernyataan Lehner dalam Gunawan (1991:42) menyatakan bahwa inflasi adalah keadaan dimana terjadi 
kelebihan permintaan terhadap barang-barang perekonomian yang pada akhirnya akan dapat meningkatkan pertumbuhan ekonomi.

\section{Populasi}

Hasil estimasi penelitian ini menunjukkan bahwa variabel jumlah populasi memiki elastisitas sebesar 0,25 persen. Nilai elastisitas tersebut memiliki arti bahwa jika jumlah populasi meningkat sebesar 1 persen akan menyebabkan pertumbuhan ekonomi negara-negara ASEAN-5 meningkat sebesar 0,24 persen.

Pertumbahan populasi memiliki dampak positif terhadap pertumbuhan ekonomi karena pertambahan jumlah populasi akan dapat meningkatkan kinerja ekspornya dan meningkatkan pengeluaran masyarakat. Hal ini merupakan efek dari tingkat adopsi dan transfer teknologi melalui investasi modal. Klasen and David (2007: 22-44) juga menyebutkan bahwa pertambahan populasi memiliki dampak positif pada keseluruhan pertumbuhan ekonomi.

\section{SIMPULAN DAN SARAN}

\section{Simpulan}

Perdagangan ekstra-regional ASEAN, investasi asing langsung, tingkat inflasi dan populasi, berpengaruh positif dan signifikan terhadap pertumbuhan ekonomi setiap negara-negara ASEAN-5 sedangkan perdagangan intra-regional ASEAN berpengaruh positif tidak signifikan terhadap pertumbuhan ekonomi setiap negara-negara ASEAN-5 dan variabel inflasi (IHK) merupakan variabel yang paling berpengaruh terhadap pertumbuhan ekonomi negara-negara ASEAN-5 disebabkan koefisien nilai inflasi memiliki nilai yang paing tinggi.

\section{Saran}

Negara-negara ASEAN-5 akan dapat meningkatkan pertumbuhan ekonomi yang lebih tinggi jika dapat meningkatkan nilai perdagangan ekstra-regional. Peningkatkan pertumbuhan ekonomi yang lebih cepat dengan memperhatikan nilai inflasi tetap pada tingkat 0-9\%. Nilai PDB pada penelitian ini adalah hasil penjumlahan antara nilai ekspor dan impor masing-masing negara ASEAN-5. Oleh sebab itu, untuk penelitian selanjutnya sebaiknya menggunakan perhitungan net ekspor dan net impor.

\section{DAFTAR PUSTAKA}

Deperindag. 2002. Implementasi AFTA Sejak 1992. Deperindag Online. (online) (http://www.depperin.go.id, diakses 5 November 2012).

Gujarati, D.N. dan Porter, D.C,.2010.Dasar-dasar Ekonometrika.Jilid 1.Edisi Kelima Mardanugraha, dkk [Penerjemah]. Jakarta: Salemba Empat.

Gunawan A.H., 1991. Anggaran Pemerintah dan Inflasi di Indonesia. Gramedia Pustaka Utama, Jakarta.

Klasen, S. and David, L. 2007. The impact of population growth on economic growth and poverty reduction in Uganda, Diskussionsbeiträge aus dem 
Volkswirtschaftlichen Seminar der Universität Göttingen, No. 133,(Online), (http://hdl.handle.net/10419/31966, diakses 3 November 2012).

Krugman, P.R. 1993.The Narrow and Broad Arguments for Free Trade. American Economic Review. (Online), The American Economic Review, 2(83), Papers and Proceedings of the Hundred and Fifth Annual Meeting of the American Economic Association (May, 1993), pp. 362-366

Krugman, P. dan Obstfeld, M.. 2004. Ekonomi Internasional Teori dan Kebijakan Edisi Kelima. Jakarta: Rajawali Persada.

Mankiw, N.G. 2007. Makroekonomi. Edisi Keenam. Liza, F dan Nurmawan, I [Penerjemah].Gelora Aksara Pratama:Jakarta.

Muchtolifah, 2010. Pengaruh Produk Domestik Regional Bruto (PDRB), Inflasi, Investasi Industri, dan Jumlah Tenaga Kerja Terhadap Pendapatan Asli Daerah (PAD) di Kota Mojokerto. Jurnal. Ilmu Ekonomi Pembangunan Vol.1 No.1 Januari 2010 : 23-29.

Nopirin. 2011. Ekonomi Internasional Edisi 3. Yogyakarta : BPFE Yogyakarta.

Salvatore, D. 1997. Ekonomi Internasional. Edisi ke-5. H. Munandar [penerjemah]. Jakarta: Erlangga.

Sukmawati, A. 2011. Analisis Faktor-Faktor yang Mempengaruhi Permintaan Ekspor Mutiara Indonesia. Skripsi : Departemen Ilmu Ekonomi. Fakultas Ekonomi dan Manajemen. Institut Pertanian Bogor. Bogor.

Todaro, M. dan Smith S.C., 2003. Pembangunan Ekonomi di Dunia Ketiga.Jilid I. Edisi Kedelapan. H. Munandar [penerjemah]. Erlangga:Jakarta.

Viner, J. 1950. The Customs Union Issue, New York: Carnegie Endowment for International Peace.

Wooster ,R.B., Dube, S., Banda, T.M., 2006. The Contribution of Intra-Regional and Extra-Regional Trade to Growth:Evidence from the European Union. 